\section{Materiality and typology of funerary heritage. The Cemetery of Jesus in Murcia, Spain}

\author{
Materialidade e tipologia do património \\ funerário. 0 Cemitério de Jesus em \\ Múrcia, Espanha
}

JOSÉ MARÍN-NICOLÁS " $^{1 *}$ MARÍA PAZ SÁEZ-PÉREZ ${ }^{2}$

1. Program in History and Arts (Territory, Heritage and Environment), University of Granada, Spain

2. Department of Architectural Constructions. Advanced Technical School of Building Engineering, University of Granada, Spain

"jomarni2@correo.ugr.es

\begin{abstract}
The cemetery of Jesus of Murcia (Spain) has more than 600 pantheons, which converts it in a small funerary city, whose buildings show a large spectrum of architectural samples. This paper presents an exhaustive study of the typologies and materials used in those little buildings. In addition, this investigation addresses the study of the evolution and the distribution of the typologies and materials detected, drawing conclusions about both of these aspects.
\end{abstract}

\section{Resumo}

O cemitério de Jesus de Múrcia (Espanha) tem mais de 600 panteões, o que faz dele uma pequena cidade funerária, cujos edifícios exibem um grande espectro de amostras arquitetónicas. Este artigo apresenta um estudo exaustivo das tipologias e materiais utilizados nesses pequenos edifícios. Além disso, esta investigação aborda o estudo da evolução e distribuição das tipologias e materiais identificados, procurando tirar conclusões sobre ambos os aspetos.

\section{KEYWORDS}

Architectural heritage

Materiality

Typology

Cemetery

Mausoleum

\section{PALAVRAS-CHAVE}

Património arquitetónico Materialidade

Tipologia

Cemitério

Mausoléu 


\section{Introduction}

The origin of the current cemeteries in the outskirts of the towns dates back, in Spain, to the end of the eighteenth century. Before that, burials were made in city centres, especially inside religious buildings, a practice that directly affected the salubrity of these areas [1]. The detonator, which meant the turning point regarding the way burials were celebrated, was the epidemic that occurred in 1780 in Pasajes (Guipúzcoa), as a result of the high number of corpses buried in the parish church [2]. After this event, the monarch Carlos III issued a Royal Order against the burial of corpses in churches [3], which was subsequently ratified in a Royal Decree, in which "the use of ventilated cemeteries" was restored [2].

The implementation process of moving the cemeteries outside city centres expanded over time. Practically until the nineteenth century, no cemetery with such characteristics had been built. This delay was due to various causes, such as economic restraints of parishes or even the reluctance of parishioners to change their burial traditions [4].

Murcia was no stranger to this process. In the years 1796 and 1811, two small cemeteries were built: Puerta de Orihuela and Puerta de Castilla, respectively [5]. As they didn't satisfied the needs of the parish in terms of capacity [1], the need for a new cemetery was imposed. After different projects and locations have been considered, the municipal architect Rodolfo Ibáñez is who, in 1883, signs what would be the final project, located in the hamlet of Espinardo, $3 \mathrm{~km}$ north from Murcia. The complete documentation of the project would be carried out by the second municipal architect, Jerónimo Ros, in 1885, with the works already on-going [5].

One of the most outstanding examples of funerary architecture are the pantheons. They are a sample of the architectural, stylistic and constructive evolution of their time, and a witness of their survival over time, due to their character as a monument to the memory. Among other aspects, it makes constructions from different periods collected in the same space. The cemeteries are, as the architect Oriol Bohigas affirms, "enormous deposits of architectural testimonies" [6]. In addition to this, studying the materials used to build the pantheons can be considered as catalogues of materiality and from them, evaluate the degradation of different materials under identical conditions, or the same materials under different specific conditions, such as the variation of the orientation or the presence or not of vegetation.

\section{The study of the funerary heritage}

Various authors have addressed the study of cemeteries from very different perspectives with a more or less specific meaning. By marking the distances, which are sometimes the true reflection of the taboo that they represent, they are treated as complementary or secondary, being related to other constructions or buildings of better recognition.
This is shown in studies about churches and chapels that are attached to the cemetery, which aim to provide a more symbolic and representative environment. For example, the study of the Cemetery of Castellnou de Bages [7] or the Chapel of a cemetery [8], where design and ornamentation prevail, forming part of global interventions, as the Contemporary Art Center of Galicia [9], being taken as a reference for new interventions, such as the Puchenau Parochial Center in Austria [10], addressing singular architectural interventions, such as the Weilimdorf cemetery, West Germany [11], or as an element of experimentation with new materials, as in the case of the Southwest cemetery in Barcelona in "the reinforced concrete in Catalonia" [12].

Complementarily, studies have been carried out in relation to the polluting capacity of cemeteries, either due to the waste material generated by their use [13] or due to inorganic soil contamination [14], or in relation to their symbology [15]. In Spain, several studies have been also dedicated to the investigation of cemeteries [1, 6, 16-20], spanning from funerary art and architecture to urbanism.

Outside the academic spectrum, there are also some works related to cemeteries in the Region of Murcia [2123]. However, these works lack a in-depth study of aspects such as the construction or the materiality, as a basis for the sustaining of the architecture, and do not cover all the cemeteries. Instead, they focus on historical, artistic and symbolic aspects of these funerary assets.

There are, however, numerous studies on the material present in heritage assets, focusing on the study of geometry and construction [24-25], mortar characterization [26], or degradation through rising damp [27], for example. Generally, these studies focus on a single building or on the behaviour of a specific material, instead of analysing large groups of architectural samples.

However, these are not frequent in other patrimonial samples of smaller size or presence in society, as is the case of cemeteries. It is observed then a lack of analysis about the architectural reality of the funerary heritage, as well as material and constructive or pathological, that constitutes previous studies that provide a solid base of knowledge about these unique buildings, without which adequate conservation, preservation and pooling and sharing, would not be feasible.

This research focuses on the study of the 627 pantheons built in cemeteries, as the clearest example of funerary architecture, with the aim of characterizing the material of each pantheon, as a necessary step before intervention, its presence, use and distribution. This analysis is considered as the study of a particular case whose conclusions can be compared with other Spanish cemeteries.

\section{Materials and methods}

\section{The Cemetery of Jesus in Murcia}

The original enclosure of the Cemetery of Jesus of Murcia 


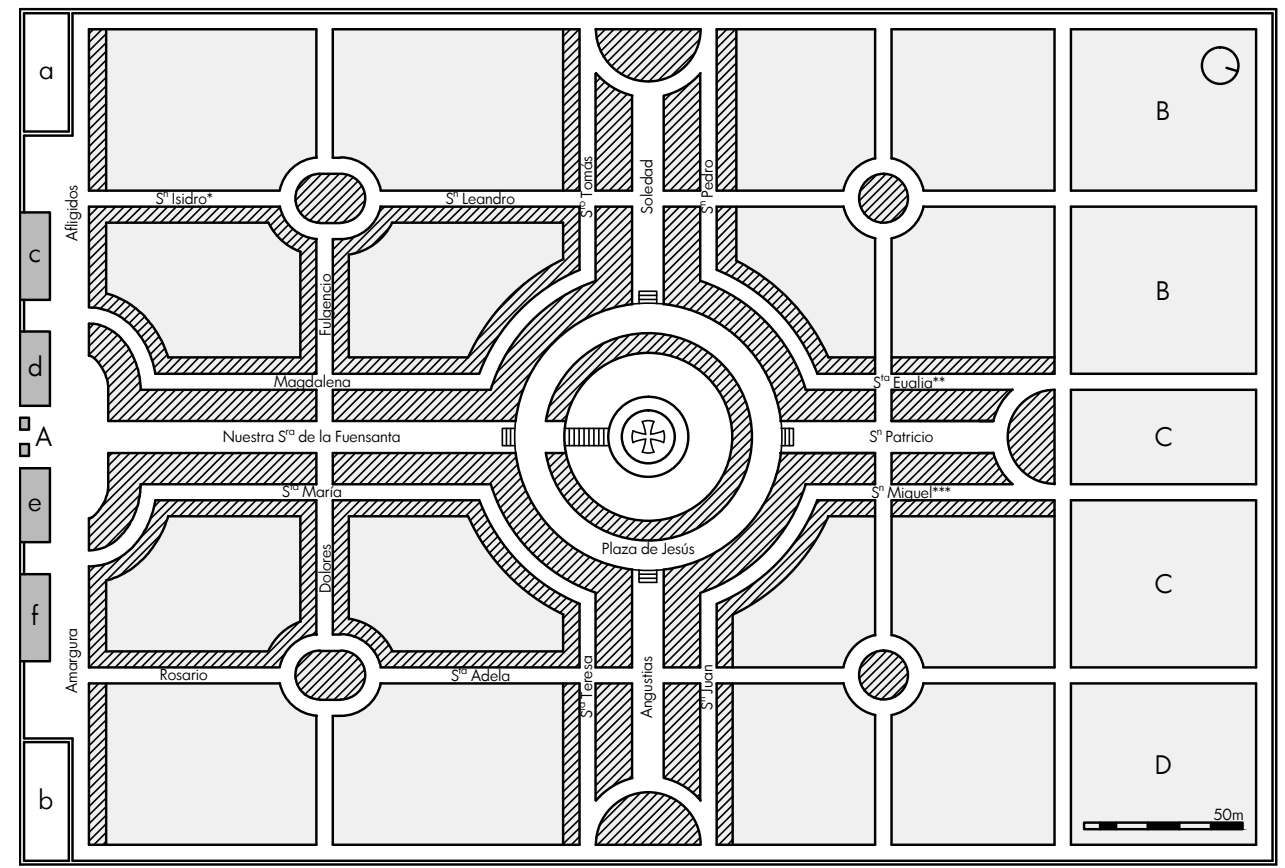

Figure 1. Floor plan of the Cemetery of Jesus. Own elaboration of the original by Jerónimo Ros, made in 1885 based on the Rodolfo Ibáñez project of 1883.

occupies a rectangle of approximately $270 \mathrm{~m}$ wide and $400 \mathrm{~m}$ long, bound by a $0.60 \mathrm{~m}$ thick perimeter wall. In the front wall are located service buildings, and the entrance is situated in the center [28]. Its interior is designed based on a Latin cross floor plan, centred on a large square, space reserved for a chapel that was never built. Following the axis of the main streets that make up the cross, approximately $6 \mathrm{~m}$ wide, are drawn parallel secondary streets of about $3 \mathrm{~m}$ wide, defining the four quadrants in which the cemetery is divided. As demonstrated in Figure 1, each of these quadrants is subdivided into sub-quadrants by the layout of tertiary streets of a section similar to the secondary streets, forming an orthogonal grid. To the north, there is an area reserved for infants and beggars. On both sides of the streets, trees alignments are projected.

In the cemetery's project, particular importance was given to the pantheons, reserving a predominant space on both sides of the main streets [29], behind which the graves where then hidden. While the surface of the graves represents $46 \%$ of the original area of the cemetery, the pantheons represent only $18 \%$. Despite this difference, and as stated by Moreno, the ornamentation of the whole cemetery rested on the pantheons [1]. The final image is a cemetery in which architecture predominates over the sculpture.

When the cemetery was inaugurated in 1887 [30], it was practically reduced to a plot of land enclosed by walls, being from that moment when its construction began, with the execution of graves and, especially, pantheons.

The chronology of the pantheons shows the advance on the occupation of the land from the access square towards the end of the original enclosure, and from the main streets to the secondary ones, as shown in Figure 2.

Until 1929, only the front wall, Fuensanta street and areas

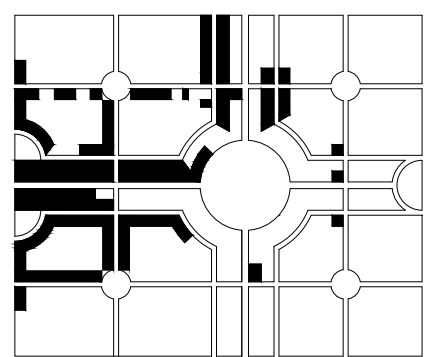

a

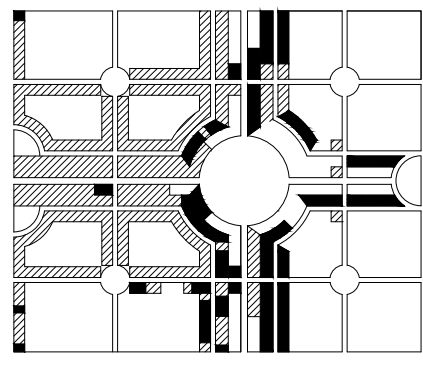

c

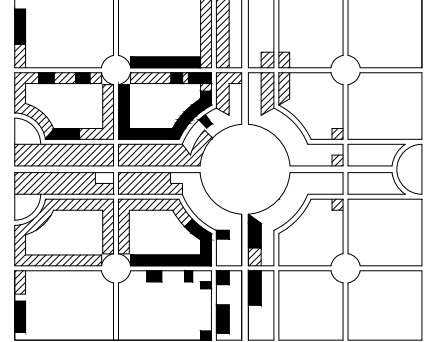

b

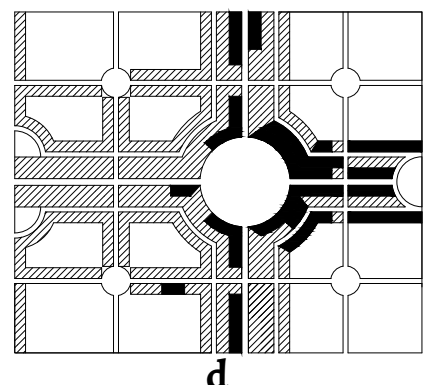

Figure 2. Chronological plan of the pantheons: (a) 1929; (b) 1956; (c) 1961; (d) 2013.

next to it, as well as some secondary streets (Santo Tomás) and isolated pantheons, was built, possibly due to the lower price of the land. Around 1956, advances are made in the central axis Angustias-Soledad, completing a significant part of the quadrants near the entrance. Between the 1940s and 1950s, the cemetery was expanded to the north, doubling its size, and following the original roadway. However, in this sector, no land is given for the construction of pantheons. In 1981, the arms of the stipites (Soledad-Angustias and its parallels) had practically been completed, and the construction began to ascend towards the upper section, constructing some lateral stretches of San Miguel and Santa Eulalia. Finally, in 2013, the upper section (St. Patrick and parallels) and Jesus 

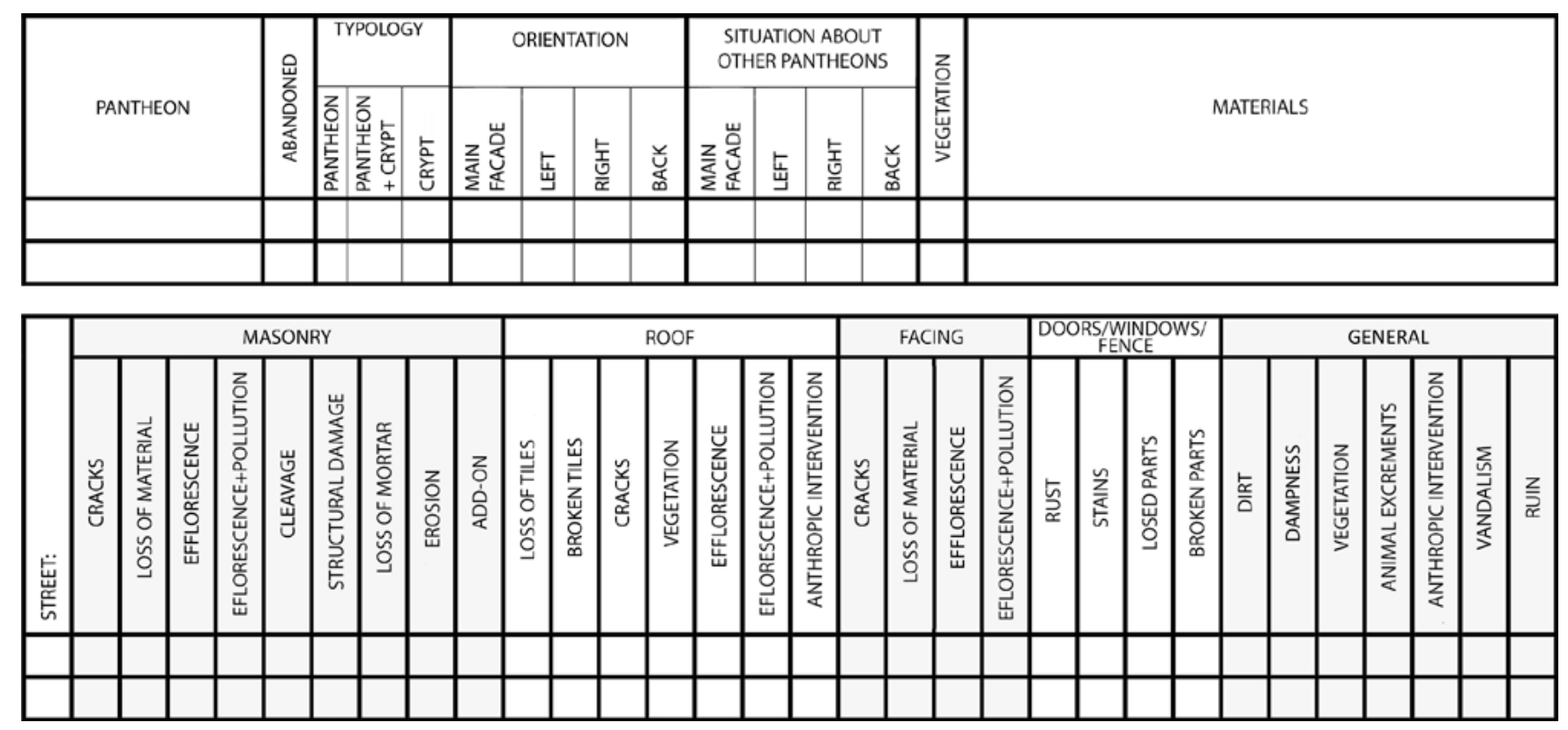

Figure 3. Data collection form.

square were completed. This delay in the construction of the central square is associated with the suppression of the chapel that originally was the most important space of the cemetery, but that had lost its transcendence over the years.

\section{The Cemetery of Jesus in Murcia}

The high volume of analysed specimens (627 pantheons) motivates the use of a methodology based on factor parameterization, allowing the handling of the large amount of information. This systematization of the analysis is specified in the realization of a data collection form in which the considered values for each evaluated parameter are collected (Figure 3). It is included, in addition to material and typological factors, other aspects that may influence the durability, or affect the pantheon, such as the orientation, density of trees or the situation to the ground or other pantheons.

The data collection in situ is done by visual inspection of the aerial parts of the pantheons, evaluating all their visible walls, and accompanied by photographs of them. At the same time, the download of files and analysis of documentation are carried out (planimetry, reports and aerial images) to complete the information.

Finally, the generated database allows the statistical analysis of the materiality and typology of the pantheons of the cemetery, while the generated planimetry allows evaluating its distribution by comparing both elements, and the drawing of conclusions.

\section{Results}

\section{The typology of the Pantheons in the cemetery of Jesus}

Typologically, three groups of pantheons were identified (Figure 4), depending on the construction situation and the burials with regards to ground level.

In the first place, there is the crypt, which is built exclusively below the ground (excluding sculptural elements), with 161 specimens, $25.7 \%$ of the total. In the second place, is the pantheon with a crypt with a chapel added just above the ground, with 98 specimens that represent $15.6 \%$ of the total sample. Finally, there is the pantheon, in which the construction was built entirely at ground level, with 368 specimens out of 627 analyzed.

Crypts and pantheons with a crypt, are the oldest typologies, and are mostly located in areas near the entrance. While the pantheon at ground level typology is by far the most represented typology, shown in a higher proportion in a

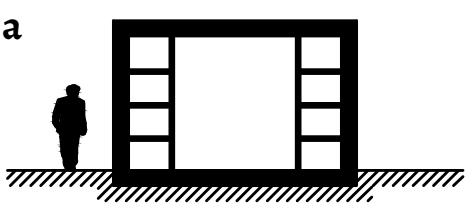

b

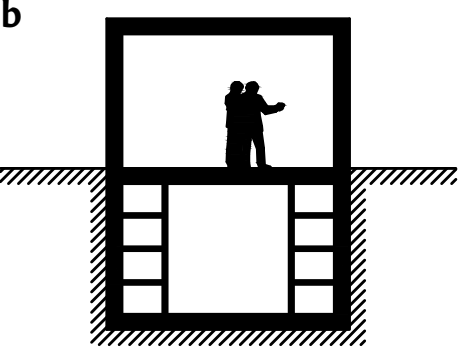

c

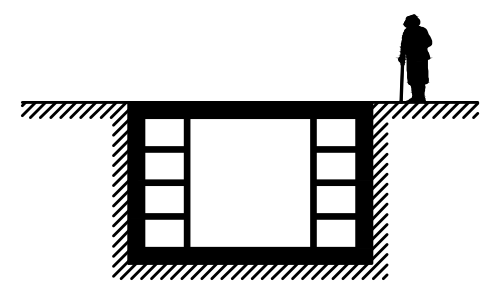

Figure 4. Typologies of pantheons: pantheon (a), pantheon with a crypt (b) and crypt (c). 
the furthest areas from the facade, they are the more recent ones. In this transition from the oldest to the newest areas of the cemetery, it is noticeable the abandonment of the underground typologies.

\section{The materiality of the Pantheons in the cemetery of Jesus}

The stone is, along with the brick, one of the basic materials that make up the enclosure and supporting structure of the pantheons. It is used in $79.6 \%$ of the sample. While a similar percentage has been observed in pantheons above ground and pantheons with a crypt (79.0\%), in underground crypts this percentage increases up to $81.4 \%$. Regarding the formats in which the material is shown, it appears fundamentally in three different forms: in blocks (ashlars), cladding (coating) and as a funerary monument (sculpture). The percentage of stone cladding is particularly high in pantheons (with or without crypt), when compacting to stone blocks, $92.1 \%$ against $7.9 \%$, respectively. This trend is inverted in the case of crypts: stone cladding is only present in $9.2 \%$ of them, while stone blocks are present in $90.8 \%$ of the specimens.

As mentioned before, brick is the second-most common material used in the construction of pantheons, with the purpose of reducing the volume of stone used. It is indeed present in $79.9 \%$ of the specimens. The study shows the predominance of coated brick, through continuous coating or cladding (in $84.0 \%$ of specimens with bricks, and in $67.1 \%$ of the total sample). Facing brick instead, is present in $52.9 \%$ of specimens with bricks, and in $42.3 \%$ of the total sample.

However, if considering the pantheons in which brick was used, $33.7 \%$ combines at the same time the material facing and coated (27.0\% of the total). So, the pantheons in which coated brick is used are reduced to $38.9 \%$ ( $48.7 \%$ of the total) while only $17.6 \%$ of the pantheon built with bricks are done exclusively with facing bricks ( $14.0 \%$ of the total).

Metal is the material that is present in the largest number of analysed samples, appearing in $98.7 \%$ of the constructions. However, except for pantheons made entirely in cast iron, metal is not the main material of the construction, being used mainly as grille against walls or metal carpentry in doors and windows. There are two types of metals that can be found: ferrous (iron and steel), which are present in $68.6 \%$ of the samples, and non-ferrous (mainly aluminium) found in $31.4 \%$ of the samples.

These percentages vary depending on the typology. In $98.1 \%$, of older crypts, ferrous metal was used, being the non-ferrous elements present in crypts the result of the substitution for the ferrous ones. In the typologies of pantheon and pantheon with crypt, greater equality is observed, using ferrous elements in $58.7 \%$ and non-ferrous in $41.3 \%$.

The lower use of aluminium in pantheons is due to the lack of construction of crypts in the most recent times, as well as the type of element in which it is used.

Of the 627 analysed constructions, $52.8 \%$ show continuous coatings. This varies depending on the typologies, being $31.7 \%$ in crypts and $60.1 \%$ in pantheons and pantheons with crypt; this difference is because the above-ground elements of the crypts are mostly limited to perimeter walls and monuments in the centre of the plot, made of uncoated stone. Regarding the type of coating, $46.5 \%$ is a traditional mortar, while $52.8 \%$ is a modern or single layer mortar.

However, the study according to the typology shows $68.3 \%$ of pantheons without a crypt (the most recent typology) with single layer mortar, while the percentage is reduced to $25.0 \%$ in the type of pantheon with crypt.

It also highlights the different presence of continuous coatings in pantheons built above ground, of the 280 coated pantheons and pantheons with crypt, $72.3 \%$ have a coating on their sides and back walls, merely for protective purposes, while in the front wall are used materials considered nobler (stone cladding or facing bricks). However, $27.7 \%$ of the pantheons have a continuous coating on all of their visible sides, including the front wall (sometimes combined with a base and/ or stone clad corners), giving it an aesthetic function in addition to the protective one.

The roofs of the pantheons above ground can be grouped into three types: inclined, (55.4\%), flat (43.1\%), and dome (1.5\%), while the crypts are completely covered by a flat roof.

The material used in inclined roofs is the ceramic tile (half-barrel, flat or mixed). Of the 258 pantheons with this type of roof, $97.7 \%$ used the roof tile as a finishing material (40.0\% of the total number of samples). The finishing of flat roofs is done with gravel or long thin bricks. In both cases, the material is hidden behind the small perimeter of the roof, which makes it impossible to determine the exact percentage of each material, although the visual inspection of some of them, visible from higher grounds, indicates a greater number of thin brick decks.

Glass is present in $70.3 \%$ of the buildings, totally linked to carpentry work and showing a strong variation between typologies. In crypts, there is a single case only, which is $0.6 \%$ of them, while in pantheons, with and without crypt, the percentage rises to $94.4 \%$.

Concrete is mainly used as the structural material in the roof of many pantheons, and by visual inspection, its use can be estimated in $60 \%$ of samples, used together with prefabricated joists and slabs. Apart from its use in the building of roofs, only two samples are found, $0.3 \%$, in which the concrete acquires the prominence of the main material.

The rest of the materials analysed during the study have very low percentages, attesting an anecdotal use. There are 10 pantheons made with concrete block, $1.6 \%$, which correspond to two distinct periods of time, the first one in the first decade of the twentieth century and the second in the last years of the twentieth century and first years of the twenty first century. The glazed ceramics tiles are shown in $7.0 \%$ of the constructions, used as a wall covering, in the same way, that artificial stone was analyzed in $5.0 \%$ of the samples.

Other materials, such as plastic or asphalt, appear in only one pantheon, so their presence in the cemetery of Jesus is residual. 

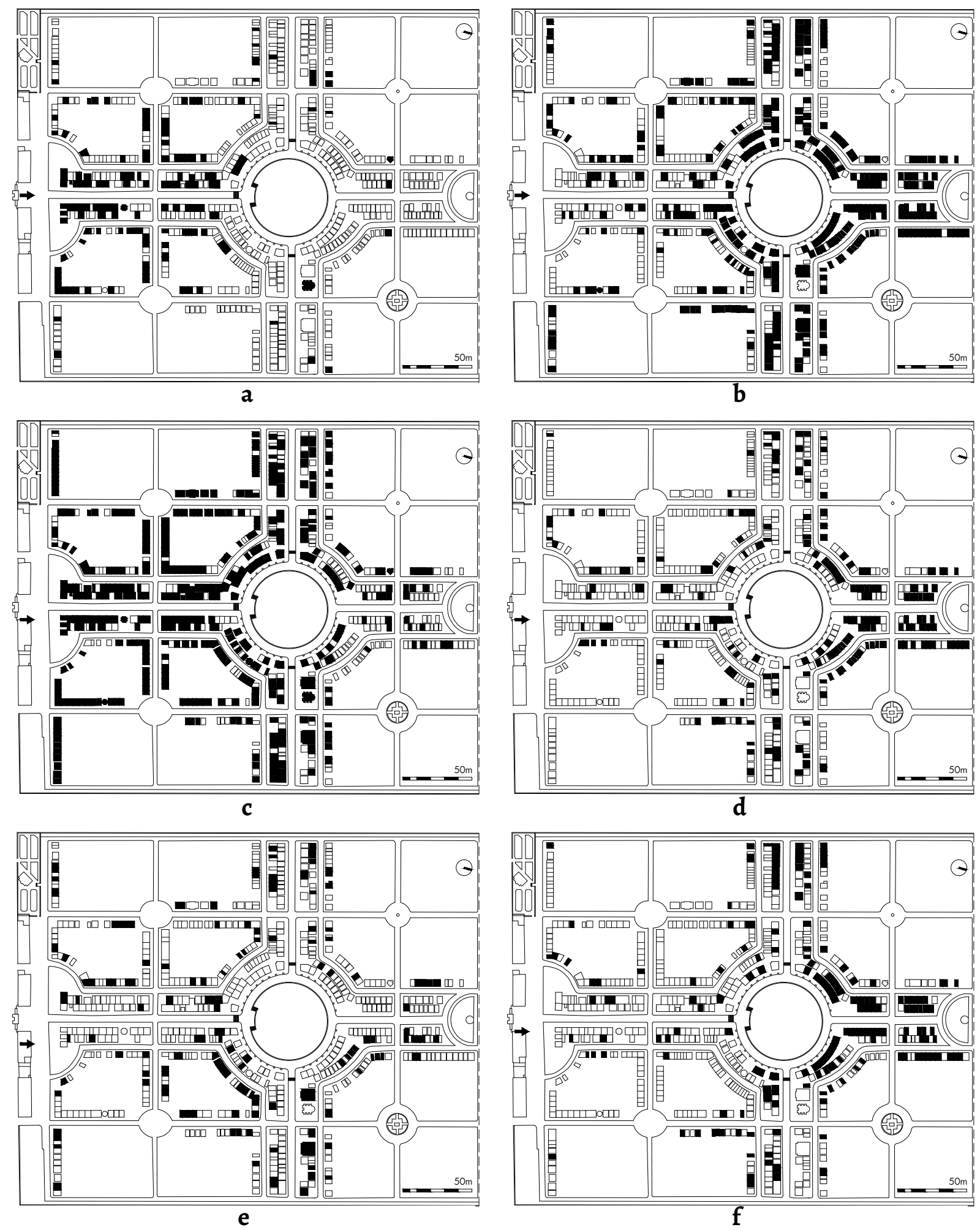

Figure 5. Pantheons' distribution plan: pantheons with stone in block (a) and cladding (b); with ferrous (c) and non ferrous metal (d); with mortars: tradicional $(e)$ and modern $(f)$.

The distribution of materials in the cemetery of Jesus

The location of the materials analysed in the cemetery's enclosure is not uniform, as is the case with the different typologies (Figure 5). Therefore, a more significant presence of stone blocks is observed in the areas near the entrance, while in the central and more remote areas, it is mainly shown in the form of cladding (Figures $5 a$ and 5b). In this transition, the brick is introduced, in the first zones, which is observed as facing bricks and generally are combined with the stones, while in the more recent zones the bricks are coated.

The distribution of metals (Figures $5 c$ and $5 d$ ), as in the cases of stone and brick, show two large differentiated zones, depending on the type of metal. Ferrous metals are predominant in the older southern quadrants of the cemetery, while in the more recent quadrants of the 
northern area of the original enclosure, almost exclusively non-ferrous metals are used.

Finally, the location of the continuous coatings shows a similar image (Figure 6). While in streets in which the pantheons were built in the first decades of the cemetery the pantheons with continuous coating represent the least number (13\% in Fuensanta street, $0 \%$ in Rosario street or $19 \%$ in San Fulgencio street), this percentage increases in streets made in the last third of the twentieth century until reaching the majority of pantheons $(96 \%$ in San Patricio street or $82 \%$ in San Miguel street), Showing intermediate numbers in the streets built between both ends. Regarding the type of mortar used in the oldest areas, there is a greater presence of traditional mortars and single layer mortars in the most recent areas (Figures $5 e$ and $5 f$ ).

The distribution of the rest of the materials shows a dispersion that does not respond to any pattern that indicates its greater concentration in any area of the cemetery, due in most cases to its lower presence.

\section{Conclusions}

In the cemetery of Our Father Jesus, it emphasizes from its ideation, at the end of the nineteenth century, the manifest interest from the local authorities to turn the necessary construction of a new cemetery into one of the great projects of the municipality, as it is deduced from the press during those days.

In the materialization of the pantheons that constitute the buildings of this necropolis, the use of a varied range of materials is shown, which are not far from those used in a house from the same period. Such a similarity shows the parallelism between the general and funerary construction, based on industry and ordinary construction professionals.

The analysis carried out shows the use of 15 different materials presented in Figure 7 according to their presence with regards to the total of pantheons.

Within this range of materials, the use of stone materials stands out associated with the idea of permanence, very appropriate to the funerary architecture, linked to the idea of eternity.

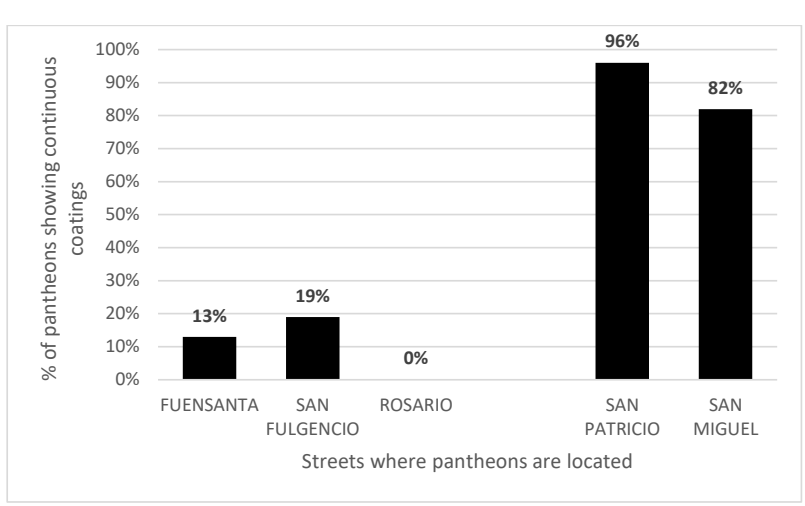

Figure 6. Percentage of pantheons showing continuous coatings.
Next to stone, brick and metal make up the most used group of materials, with percentages above $75 \%$. A second group of materials: glass, concrete, mortar and ceramic tiles is between $25 \%$ and $75 \%$ of the total and, finally, below $25 \%$ : wood, concrete slab, glazed ceramic, artificial stone, concrete block, asphalt, plastic and sheet metal are detected.

In the Cemetery of Jesus, the pantheons show the duality of evolution and, at the same time, continuity. The introduction of new materials or techniques is appreciated and, at the same time, the material uniformity of the pantheons. Stone, brick and metal clearly show the aforementioned continuity of the materials. The case of the stone is particularly striking, which is maintained from the first pantheons of the 1880 s to those built today, although with variations.

Regarding the evolution of the materiality, the incorporation of new materials or techniques is observed, which, however, are not making significant changes. (because volume, composition and symbology remain). Therefore, the brick replaces the stone as a bearing wall, but stone cladding continues to be used to seek visual continuity. Also in ornamental elements, such as mouldings, the stone is replaced by brick, sometimes coated, and more recently by artificial stone.

As an exception to this material uniformity, there are pantheons in which the material conception associated with the type of construction seems to overcome and which constitutes examples of new materiality, possible pantheons in which the metal, the concrete, the concrete block or the glass suppose a variation in the continuity of the material conventionally accepted in funerary architecture although this does not contravene the prevailing typological continuity.

On the contrary, it is in hidden elements where the materiality evolves the most because by not being visible, no impediment is found for changing one material for another. In this way, the roofs with timber battens and roof tiles are being replaced by others of concrete joist and slabs, also covered by ceramic roof tiles.

The evolution and substitution of the materiality, as well as the typological variation, can be linked to the suppression of crypts, aimed at saving material and, as a consequence, reducing the cost. This phenomenon can be appreciated in the reduction of stone blocks used, coinciding the pantheons made entirely with this material with the first years of the enclosure. While those built immediately in later years reduce the use of the stone mainly for the base, corners and representative elements, such as the facades, while the rest of the construction is done using bricks. Afterwards stone blocks are all removed, making the pantheon entirely in brick and stone cladding.

This evolutionary process is also shown in the introduction of materials to replace others, as it is the use of the continuous coatings, applied on the lateral walls, in substitution for stone cladding, while their use remains in the front walls. 


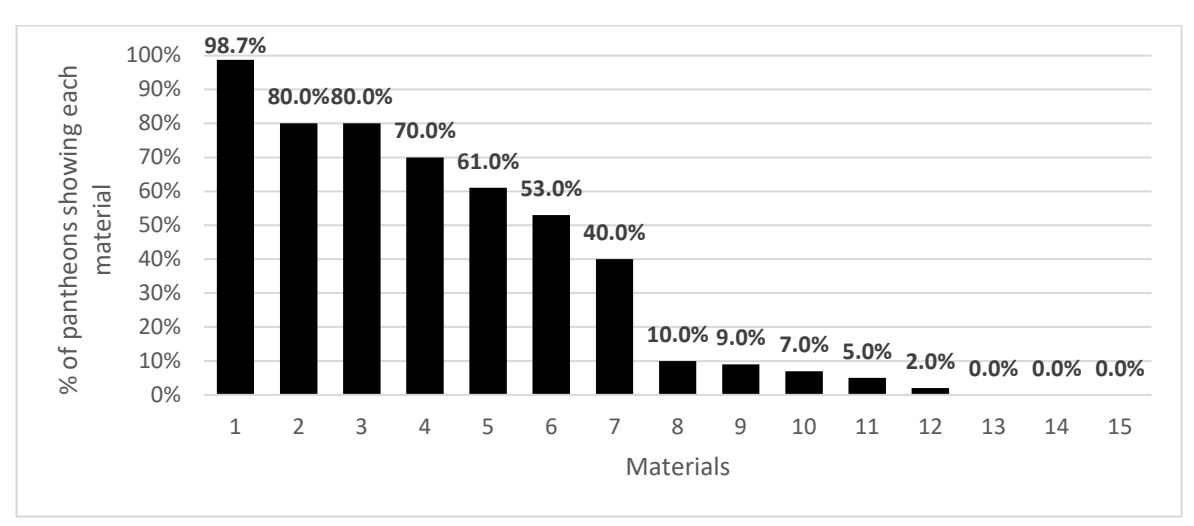

Figure 7. Percentage of pantheons by material: 1-metal, 2-stone, 3-brick, 4-glass, 5-concrete, 6-continuous coating, 7-roof tile, 8-wood, 9-cement tile, 10Ceramic glaze, 11-artificial stone, 12-concrete brick, 13-asphalt, 14-plastic, 15-sheet iron.

In the first decades of the twentieth century along with the saving in material, the experimentation with new materials supposes a cause of evolution in the cemetery, as shown the presence of pantheons built with concrete blocks or with artificial stones, or the samples of more modern materials such as plastic.

However, the use of new materials is punctual, evidencing the reluctance of the society and professionals, or both, in to change the variation in the design of the funerary buildings.

In conclusion, cemeteries are experimentation fields, because they collect a large number of architectural samples in the same space and under the same environmental conditions, which act in the same way on different construction solutions, something difficult to achieve with other types of buildings.

To this is added the possibility of, within these same conditions, finding similar samples subjected to different variations. Therefore, practically identical pantheons with opposite orientations can be analysed, where one of them is wrapped in dense vegetation while the other one lacks it.

The study of the materiality of the cemetery of Jesus shows an evolution in the use of materials typical of a construction industry that, far from isolated and independent, keeps total relation with the rest of the city and, at the same time, a conservative tendency that seeks to continue associating the pantheon with the traditional idea of it which is a matter of materiality in the same way as of composition, and which rarely transgresses. Knowing the material and typological reality of the funerary heritage is a necessary step, the same than in any other building, for an adequate intervention, conservation and enhancement.

Works with similar characteristics on materiality or typology in heritage are fundamental as a preliminary step both for the intervention as for the drawing of a conservation plan, as shown by studies carried out on the typology and materiality of Bragança buildings prior to the assessment of degradation produced by moisture [31], characterization of materials from the cathedral of S. Giorgio (Ragusa Ibla, Italy), to analyse its chromatic alteration [32], the use of stone in the Australian architectural heritage [33] or the analysis of the materiality of Ethiopian architecture for the restoration of historical-artistic heritage [34], to cite some examples.

This importance is especially relevant in situations where a large number of samples are being worked on, as is the case of urban centres, or when these show very particular characteristics that hold significance regarding a general construction, either due to lower demand of functional and/ or legal characteristics or specific uses. Both situations are reflected in the study object selected in this analysis.

Thus, the knowledge of the materials with the highest proportion, as well as their location in the site, which is directly related to their age, in an area where exposure to degradation is similar for all buildings, allows us to anticipate strategies for maintenance and intervention (more degraded materials, zoning of them), generating an instrumental knowledge for a conservation plan in a next stage.

The specific case of the funerary construction means, in addition, the added circumstance that the subject represents the support of the memory, the reason to preserve it allows maintaining its authenticity and its history, keeping the function for which these constructions were created, that of a memorial monument.

\section{REFERENCES}

1. Moreno, A. M., Cementerios murcianos: arte y arquitectura, $\mathrm{PhD}$ thesis, University of Murcia, Murcia, Spain (2005).

2. Real Cédula de 3 de abril de 1787 de S.M. y Señores del Consejo en que por punto general se manda restablecer el uso de Cementerios ventilados para sepultar los cadáveres de los Fieles, y que se observe la ley 11. tit. 13. de la Partida Primera, que trata de los que podrán enterrarse en las Iglesias, con las adicciones y reclamaciones que se expresan (1787).

3. Grangel, M.; Carreras Panchón, A., 'Extremadura y el debate sobre la creación de cementerios: un problema de salud pública em la ilustración', Norva: Revista de Historia 17 (2004) 123-125, https://dialnet.unirioja.es/servlet/ articulo?codigo $=1158934$

4. Santonja, J. L., 'La construcción de cementerios extramuros: un aspecto de la lucha contra la mortalidad en el antiguo régimen', Revista de historia moderna 17 (1998-99) 33-44, https:// core.ac.uk/download/pdf/16358452.pdf 
5. Gómez, D. N., Arquitectura y arquitectos del siglo XIX en Murcia, Ayuntamiento de Murcia, Murcia, Spain (1993).

6. Bohigas i Guardiola, O., 'Los cementerios como catálogo de arquitectura', CAU: construcción, arquitectura y urbanismo 17 (1973) 56-58, https://dialnet.unirioja.es/servlet/ articulo?codigo $=2614962$.

7. Moreno-Navarro, A. G., 'Nuevo cementerio municipal de Castellnou de Bages (Barcelona, España)' Informes de la Construcción 52(471) (2001) 5-19, http://doi.org/fvgx5b.

8. Wurster y Huggel, arquitectos, 'Capilla de un cementerio', Informes de la Construcción 10(97) (1958) 27-34, http://doi.org/ cwx5.

9. Siza Vieira, A., 'Centro de arte contemporáneo de Galicia en Santiago de Compostela (Galicia, España)', Informes de la Construcción 47(439) (1995) 42-57, http://doi.org/fkwdsr.

10. Rainer, R., 'Centro Parroquial en Purcheau, Austria', Informes de la Construcción 31(308) (1979) 11-18, http://doi.org/cwx6.

11. Kammerer, H., 'Development of a physical model of a typical nineteenth-century English canvas painting', Informes de la Construcción 22(212) (1969) 27-31, http://doi.org/cwx7.

12. Graus, R.; Martín Nieva, H.; Rosell, J., 'El hormigón armado en Cataluña (1898-1929): cuatro empresas y su relación con la arquitectura', Informes de la Construcción 69(546) (2016), http:// dx.doi.org/10.3989/ic.16.004.

13. Jonker, C.; Oliver, J., 'Mineral Contamination from Cemetery Soils: Case Study of Zandfontein Cemetery, South Africa', International Journal of Environmental Research and Public Health 9(2) (2012) 511-520, http://doi.org/gchntm.

14. Spongberg, A. L.; Becks, P. M., 'Inorganic soil contamination from cemetery Leachate', Water, Air, and Soil Pollution 117 (2000) 313-327, http://doi.org/c3z4k3.

15. Ross, S., Acadian Cemeteries. Sally Ross Research Collection, in Nova Scotia, https://novascotia.ca/archives/cemeteriesacadian/default.asp (accessed 2018-11-21).

16. Lorenzo, C. B., Arte y arquitectura funeraria. Los cementerios de Asturias, Cantabria y Vizcaya (1787-1936), University of Oviedo, Oviedo, Spain (1998).

17. Quer, C. S., Arquitectura funeraria madrileña del siglo XIX, PhD Thesis, Complutense University of Madrid, Madrid, Spain (1989).

18. García, L. V. P., Los Cementerios de la Provincia de Cádiz. Arte, Sociología y Antropología, PhD Thesis, University of Málaga, Málaga, Spain (2016).

19. Gómez, D. N., Arquitectura y arquitectos del siglo XIX en Murcia, PhD Thesis, University of Murcia, Murcia, Spain (1991).

20. Rojas, F. J. P., Arquitectura y Urbanismo en Cartagena (1874-1936), PhD Thesis, University of Valencia, Valencia, Spain (1984).

21. Gómez, D. N., 'El Estilo Neogótico a finales del siglo XIX en la arquitectura funeraria del cementerio de Ntro. Padre Jesús en Murcia y en otros cementerios del municipio', Murgetana 85 (1992) 21-32, https://dialnet.unirioja.es/servlet/ articulo? codigo $=2668951$.

22. Ramírez, J. B. V., 'El Cementerio británico de Cartagena, primera necrópolis protestante en la Región de Murcia (18461874)', Anales de la historia contemporánea 15 (1999) 385-412, https://dialnet.unirioja.es/servlet/articulo? codigo $=237126$.

23. Martínez, F. J. D., 'Espacios funerarios, arquitectura, narrativa y rito en el ámbito de Yecla (Región de Murcia)', in El mundo de los difuntos. Culto, cofradías y tradiciones, ed. F. J. Campos, F. De Sevilla, vol. 2, Ediciones Escurialenses, San Lorenzo del Escorial (2004), https://dialnet.unirioja.es/servlet/ articulo? codigo $=5044089$.

24. Martínez R. J.; Areces, E. A.; Menduiña, J.; Rubí, J. A. M., 'Materiales utilizados en el patrimonio arquitectónico: la arenisca roja de la catedral de Astorga (León)', Boletín Geológico y Minero 120(1) (2009) 45-52, http://www.igme.es/ Boletin/2009/120_1_2009/ARTICULO\%204.pdf.

25. Pérez-Sánchez, J. C.; Piedecausa-García, B., 'Cúpulas de crucero en templos de la provincia de Alicante (s.XVII-XIX): construcción y geometría', Informes de la Construcción, 67(538) (2015) e077, http://dx.doi.org/10.3989/ic.13.176.

26. Igea, J.; Lapuente, P.; Martínez-Ramírez, S.; Blanco-Varela, M. T., 'Caracterización de morteros mudéjares de la iglesia de San Gil Abad (Zaragoza, España): investigación de la tecnología de fabricación de morteros históricos de yeso', Materiales de Construcción 62(308) (2012) 515-529, http://dx.doi. org/10.3989/mc.2012.07311.

27. Camino, M. S.; León, F. J.; Llorente, A.; Olivar, J. M., 'Evaluation of the behavior of brick tile masonry and mortar due to capillary rise of moisture', Materiales de Construcción 64(314) (2014) eo20, http://dx.doi.org/10.3989/mc.2014.02513.

28. Archivo Municipal de Murcia. Cementerio. Legajo 10, expediente 1.

29. Reglamento para el Régimen, Gobierno y Administración Económica del Cementerio General de la Ciudad de Murcia, bajo la advocación de Ntro. Padre Jesús. Ayuntamiento de Murcia (1884).

30. La Bendición (7 de junio de 1887). El Diario de Murcia, p. 1 (1887).

31. Lourenço, P. B.; Luso, E.; Almeida, M. G., 'Defects and moisture problems in buildings from historical city centres: a case study in Portugal', Building and Environment 41(2) (2006) 223-234, https://doi.org/10.1016/j.buildenv.2005.01.001.

32. Barone, G.; La Russa, M. F.; Lo Giudice, A.; Mazzoleni, P.; Pezzino, A., 'The Cathedral of S. Giorgio in Ragusa Ibla (Italy): characterization of construction materials and their chromatic alteration', Environmental Geology 55(3) (2008) 499504, https://doi.org/10.1007/s00254-007-0995-0.

33. Cooper, B. J., 'Heritage stone in South Australia, Australian Journal of Earth Sciences', Australian Journal of Earth Sciences 66(6) (2006) 947-953, https://doi.org/10.1080/08120099.2018.1 547323.

34. Durán-Suárez, J. A.; Sáez-Pérez, M. P., 'Characterization of Classical Construction Materials used in Ethiopian Architecture for the Restoration of their Historic and Artistic Heritage', International Journal of Architectural Heritage 13(6) (2018) 855-869, https://doi.org/10.1080/15583058.2018.148 9014.

RECEIVED: 2019.3.15

REVISED: 2019.4.22

ACCEPTED: 2020.6 .30

ONLINE: 2020.5 .4

\section{(c) (1) $(-)$}

This work is licensed under the Creative Commons Attribution-NonCommercial-NoDerivatives 4.0 International License. To view a copy of this license, visit http://creativecommons.org/licenses/by-nc-nd/4.o/deed.en. 